\title{
Effect of 3 Months Exercise on Ovarian Reserve and Ovulatory Status of Premenopausal Students of Nnamdi Azikiwe University, Nnewi Campus
}

\author{
Njoku CM${ }^{1}$, Meludu SC², Dioka CE ${ }^{1}$, Umunnah $\mathrm{JO}^{3}$, Onyegbule OA ${ }^{1}$, \\ Olisah $\mathrm{MC}^{4}$, Bamigbowu $\mathrm{EO}^{5}$
}

\begin{abstract}
${ }^{1}$ Department of Chemical Pathology, Faculty of Basic Clinical Sciences, Nnamdi Azikiwe University, Awka, Nigeria.

${ }^{2}$ Department of Human Biochemistry, Faculty of Basic Medical Sciences, Nnamdi Azikiwe University, Awka, Nigeria.

${ }^{3}$ Department of Medical Rehabilitation, Nnamdi Azikiwe University, Awka, Nigeria.

${ }^{4}$ Department of Medical Biochemistry, Chukwuemeka Odumegwu Ojukwu University, Uli, Nigeria.

${ }^{5}$ Department of Chemical Pathology, University of Port Harcourt, Rivers State, Nigeria.
\end{abstract}

Corresponding Author: Njoku CM

DOI: https://doi.org/10.52403/ijhsr.20220111

\begin{abstract}
There is a traditional believe that if premenopausal women engage in prolonged physical exercise, they are likely to have infertility. This study assessed the effect of prolonged moderate - vigorous exercise on ovarian reserve and ovulatory status in premenopausal students of Nnamdi Azikiwe University, Nnewi Campus. The objectives were to determine the effect of moderate - vigorous intensity exercise on Anti-Mullerian hormone (AMH), day 3 Follicle stimulating hormone (FSH), Luteinizing Hormone (LH), day 3 Estrogen, day 21 Estrogen, and day 21 Progesterone levels in premenopausal women. This was a prospective comparative study involving 80 participants aged between 19 and 25 years, randomly selected and assigned to exercise group and control group. The exercise group comprised 40 participants who engaged in moderate - vigorous intensity exercise using elliptical bike for 30 minutes, five days a week for 3 months; however, 30 individuals completed the exercise. The control group comprised of 40 individuals that did not do exercise but 30 individuals completed the study. Blood (8ml) was collected from each of the participants at baseline, 1 month, 2 months, and 3 months. AMH, FSH, LH, Estrogen and Progesterone levels were analyzed using enzyme- linked Immunosorbent assay (ELISA) method. Results were regarded as significant at $\mathrm{p}<0.05$. In the exercise group, the serum level of day $3 \mathrm{FSH}$, LH, Estrogen were significantly lower from $7.27 \pm 0.77 \mathrm{mIU} / \mathrm{ml}, 7.00 \pm 0.77 \mathrm{mIU} / \mathrm{ml}, 36.33 \pm 5.13 \mathrm{pg} / \mathrm{ml}$ respectively at baseline to $5.62 \pm 0.48$ $\mathrm{mIU} / \mathrm{ml}, 5.36 \pm 0.80 \mathrm{mIU} / \mathrm{ml}, 21.36 \pm 4.34 \mathrm{pg} / \mathrm{ml}$ respectively after 3 months of exercise while there was significantly higher levels of AMH and day 21 progesterone after 3 months of exercise compared with the baseline and respective control $(\mathrm{p}<0.05)$. Prolonged Moderate-to-vigorous exercise may enhance fertility and well-being of premenopausal women.
\end{abstract}

Key Words: Anti-Mullerian hormone (AMH), day 3 Follicle stimulating hormone (FSH), Luteinizing Hormone (LH), day 3 Estrogen, day 21 Estrogen, day 21 Progesterone, moderate - vigorous exercise, ovarian reserve, ovulatory status, premenopausal women.

\section{INTRODUCTION}

Physical activity is defined as each bodily movement formed by contraction of skeletal muscles that significantly rises energy expenditure (1). Physical exercise is a subsection of Leisure-time physical activity (LTPA) that is scheduled, designed, repetitive, and purposive for enhancement 
or upkeep of physical fitness (1). It is usually grouped into three, namely, flexibility exercise (2), aerobic exercise (3), and anaerobic exercise (4). Over the past three decades, main social changes have encouraged the development of a positive attitude towards physical exercise in general. Hence, women are becoming increasingly involved in physical activities, ranging from regular mild exercise to highly competitive performance requiring intensive and strenuous training. The beneficial role of exercise in the promotion of both mental and physical health is indisputable. Regular exercise can increase insulin sensitivity, help blood glucose control, and prevent or delay the development of diabetes complications (5-6). Physical exercise guards ovarian function (7), enhance ovulatory status in young females (8) and lead to a significant improvement in fertility (9). Several organizations including the World Health Organization (WHO) and the American College of Sports Medicine, have declared recommendations to the public for physical activity. They supported that to reduce the risk of chronic diseases and improve overall health status, people of all ages should perform a minimum of 30 minutes of moderate-intensity physical activity on most days of the week (10). They also highlight that greater health benefits can be derived from physical activity that is more vigorous and longer in duration (10). However, as the current general trend is towards considerable increase in the duration, frequency and intensity of exercise, great concern is arising with regard to the harmful effects of intensive physical exercise on female sex hormones and fertility.

Hormones are specific regulatory molecules that modulate reproduction, growth, development and the maintenance of internal environments as well as energy production, utilization and storage (11). Regular and healthy reproductive cycle (eumenorrhea) is a complex process comprising the coordinated interaction of neurotransmitter systems, hypothalamic releasing factors, anterior pituitary gland hormones, gonadal sex steroid hormones, and various growth factors. Ovarian hormones such as estrogen and progesterone are main hormones for female reproductive and menstrual cycle. The ovarian cycle is stimulated by hormones in the circulation, i.e. follicle-stimulating hormone (FSH) and luteinizing hormone (LH), which are, in turn, regulated by the hypothalamic gonadotropin releasing hormone (GnRH). GnRH released by hypothalamus stimulates anterior pituitary gland to release LH and FSH. These hormones enhance ova, i.e. egg development in ovaries (12). Anovulation is failure of the ovaries to produce, mature, or release ova. The condition may result from ovarian immaturity or postmaturity; altered ovarian function, as in disturbed interaction of the hypothalamus, pituitary gland and ovary caused by stress or disease. Anovulatory infertility is thought to be one of the leading causes of female infertility (13). Infertility is defined as inability to conceive a child by a couple in a stable relationship during the year of regular intercourse without the use of contraceptive methods (14). Experiences from clinical practice in Nigeria indicate that infertility is a major burden on clinical service delivery in Nigeria (15). Infertile obese women who experienced weight loss (about $10 \mathrm{~kg} / \mathrm{m} \mathrm{2}$ ) through diet and exercise intervention, resumed spontaneous ovulation, achieved spontaneous pregnancy, had lower miscarriage rates, and increased live birth (16). Also, Atuegbu et al., reported that Moderate -to-vigorous exercise causes some changes in the reproductive hormones including estrogen, LH, FSH and significant increase in progesterone hormone levels after one month of exercise and they concluded that the hormonal pattern shows that moderate-to-vigorous exercise may enhance ovulatory status in young females (8). Therefore, prolonged moderate -to vigorous intensity exercise may also have the same or contrary effect on some fertility hormones. The most commonly encountered fertility hormones include LH, FSH, 
estrogen, Anti-Mullerian hormone (AMH), and Progesterone.Elevation in serum levels of progesterone is an indirect evidence of ovulation. The lower limits of progesterone levels in the luteal phase vary among laboratories but a level of more than 3ng/mL confirms ovulation (17). In a regularly menstruating woman, the midluteal phase (typical day 21-23) is the period of peak progesterone secretion from the corpus luteum and the serum progesterone level remains at a fairly constant high level.

The term "ovarian reserve" refers to the quantity and quality of a woman's current reservoir of oocytes, and is closely associated with reproductive potential. It is an indirect measure of a woman's reproductive age (18). Some of biological markers have been identified to estimate the ovarian reserve such as the evaluation of serum levels of follicle stimulating hormone (FSH), Anti-Mullerian hormone (AMH), inhibin B, estradiol, (E2) and antral follicle count (AFC). These are the commonly used ovarian reserve markers for assessing ovarian reserve in the women of reproductive age (19-22). Early follicular phase FSH elevations observed in older reproductive aged women may not only be due to a decrease in the number of recruitable follicles (and the resulting decrease in negative feedback), but may also be due to a relative resistance of the follicles to gonadotrophins (23). AntiMullerian hormone (AMH), a hormone originally known to inhibit the development of Mullerian ducts in male embryos, has been shown to be an excellent marker of ovarian reserve in women (24). AMH is secreted by the granulosa cells of the preantral and small antral follicles and inhibits the initial and cyclic recruitment of follicles (25). Serum AMH declines as age increases in women over 25 years of age (26), and has been shown to be as effective of a predictor of the ovarian response during controlled ovarian hyper stimulation as antral follicle counts (AFCs) (24). It has also been shown to help predict early ovarian follicle loss and the onset of menopause; and is defined as a reliable predictor of ovarian reserve (27). In addition, $\mathrm{AMH}$ is increasingly used in clinical practice for both prognostic purposes (28) such as prediction of ovarian response during in vitro fertilization treatment (IVF) and diagnostic purposes such as the identification of women with premature ovarian failure (POF) or polycystic ovarian syndrome (PCOS) can be possible $(19,29)$.

Moreover, serum AMH exhibits less intra and intercycle variation than AFCs, suggesting that AMH may be a more reliable means of assessing ovarian reserve (30). It is well documented that the female reproductive system is highly sensitive to changes regarding both intrinsic and extrinsic factors. Thus, females who are exposed to intensive physical exercise and associated psychological stress are prone to developing reproductive dysfunction.

\section{METHODOLOGY}

This was a prospective comparative study involving 80 participants aged between 19 and 25 years, randomly selected and assigned to exercise group and control group. The exercise group comprised 40 participants who engaged in moderate vigorous intensity exercise using elliptical bike for 30 minutes, five days a week for 3 months; however, 30 individuals completed the exercise. The control group comprised of 40 individuals that did not do exercise but 30 individuals completed the study. Blood $(8 \mathrm{ml})$ was collected from each of the participants at baseline, 1 month, 2 months, and 3 months. AMH, FSH, LH, Estrogen, Progesterone was analyzed using enzymelinked Immunosorbent assay (ELISA) method.

\section{RESULT}

Table 1 shows the ovarian reserve, using serum Estrogen, FSH, LH and AMH of exercise and non-exercise group over a 3 months period.

The mean levels of Estrogen and LH showed significant reduction at 1 month, 2 
Njoku CM et.al. Effect of 3 months exercise on ovarian reserve and ovulatory status of premenopausal students of Nnamdi Azikiwe University, Nnewi Campus.

months and 3 months of exercise while FSH significant reduction was observed at 2 months and 3 months of exercise compared with their respective control $(\mathrm{p}<0.05)$. Conversely, AMH was significantly increased at 3 months of exercise when compared with its respective control $(\mathrm{p}<0.05)$. At different stages of Exercise; significant progressive reductions were observed in Estrogen, FSH and $\mathrm{LH}$ at 1 month, 2 months and 3 months of exercise when compared with baseline $(\mathrm{p}<0.05)$. However, AMH showed significant increase at 3 months of exercise when compared with baseline $(\mathrm{p}<0.05)$.

Ovulatory Parameters of Exercise Group and Non-Exercise Group are shown in table 2.

Table 1: The Ovarian reserve, using serum Estrogen, FSH, LH and AMH of exercise and non-exercise group over a 3 months period $($ Mean \pm SD).

\begin{tabular}{|c|c|c|c|c|c|}
\hline \multirow[t]{2}{*}{ Parameters } & \multirow{2}{*}{ Period } & \multicolumn{2}{|l|}{ Group } & \multirow[t]{2}{*}{ t-value } & \multirow[t]{2}{*}{ P-value } \\
\hline & & Exercise $(n=30)$ & Non-exercise $(n=30)$ & & \\
\hline \multirow{4}{*}{ Estrogen(pg/ml) } & Baseline & $36.33 \pm 5.13$ & $35.68 \pm 5.06$ & 0.494 & 0.623 \\
\hline & $1^{\text {st }}$ Month & $30.62 \pm 4.69^{a}$ & $36.03 \pm 4.88$ & -4.380 & $<.001^{*}$ \\
\hline & $2^{\text {nd }}$ Month & $25.65 \pm 4.51^{\mathrm{ab}}$ & $35.22 \pm 4.6$ & -8.135 & $<.001^{*}$ \\
\hline & $3^{\text {rd }}$ Month & $21.36 \pm 4.34^{\mathrm{abc}}$ & $35.38 \pm 5.27$ & -11.253 & $<.001^{*}$ \\
\hline \multirow[t]{4}{*}{$\mathrm{FSH}(\mathrm{mIU} / \mathrm{ml})$} & Baseline & $7.27 \pm 0.77$ & $7.21 \pm 1.51$ & -0.204 & 0.839 \\
\hline & $1^{\text {st }}$ Month & $6.78 \pm 0.55^{\mathrm{a}}$ & $7.22 \pm 1.29$ & 1.713 & 0.092 \\
\hline & $2^{\text {nd }}$ Month & $6.21 \pm 0.46^{\mathrm{ab}}$ & $7.36 \pm 1.16$ & 5.006 & $<.001^{*}$ \\
\hline & $3^{\text {rd }}$ Month & $5.62 \pm 0.48^{\mathrm{abc}}$ & $7.33 \pm 1.62$ & 5.512 & $<.001^{*}$ \\
\hline \multirow[t]{4}{*}{$\mathrm{LH}(\mathrm{mIU} / \mathrm{ml})$} & Baseline & $7.00 \pm 0.77$ & $6.89 \pm 0.61$ & 0.624 & 0.535 \\
\hline & $1^{\text {st }}$ Month & $6.49 \pm 0.75^{\mathrm{a}}$ & $6.85 \pm 0.62$ & -2.013 & $0.049 *$ \\
\hline & $2^{\text {nd }}$ Month & $5.92 \pm 0.78^{\mathrm{ab}}$ & $6.81 \pm 0.66$ & -4.720 & $<.001^{*}$ \\
\hline & $3^{\text {rd }}$ Month & $5.36 \pm 0.80^{\mathrm{abc}}$ & $6.90 \pm 0.69$ & -7.918 & $<.001^{*}$ \\
\hline \multirow[t]{4}{*}{ AMH(ng/dl) } & Baseline & $3.16 \pm 0.02$ & $3.16 \pm 0.03$ & 0.097 & 0.923 \\
\hline & $1^{\text {st }}$ Month & $3.16 \pm 0.02$ & $3.16 \pm 0.02$ & 0.246 & 0.806 \\
\hline & $2^{\text {nd }}$ Month & $3.16 \pm 0.02$ & $3.16 \pm 0.02$ & 0.095 & 0.924 \\
\hline & $3^{\text {rd }}$ Month & $3.17 \pm 0.02^{\mathrm{a}}$ & $3.16 \pm 0.02$ & 2.269 & $0.027 *$ \\
\hline
\end{tabular}

$a=p<0.05$ compared with baseline, $b=p<0.05$ compared with $1^{\text {st }}$ month, $c=p<0.05$ compared with $2^{\text {nd }}$ month, $d=p<0.05$ compared with $3^{\text {rd }}$ month.

Table 2: The Ovulatory Status using Estrogen and Progesterone of exercise and non-exercise group over a period of 3 months (Mean \pm SD).

\begin{tabular}{|c|c|c|c|c|c|}
\hline \multirow[t]{2}{*}{ Parameters } & \multirow[t]{2}{*}{ Period } & \multicolumn{2}{|l|}{ Group } & \multirow[t]{2}{*}{ t-value } & \multirow[t]{2}{*}{ p-value } \\
\hline & & Exercise $(n=30)$ & Non-exercise $(n=30)$ & & \\
\hline \multirow{4}{*}{$\begin{array}{l}\text { Estrogen }(\mathrm{pg} / \mathrm{ml}) \\
\text { (Day 21) }\end{array}$} & Baseline & $79.91 \pm 0.72$ & $80.14 \pm 0.63$ & -1.288 & 0.203 \\
\hline & $1^{\text {st }}$ Month & $75.09 \pm 0.73^{\mathrm{a}}$ & $79.94 \pm 0.69$ & -26.328 & $<.001^{*}$ \\
\hline & $2^{\text {nd }}$ Month & $70.23 \pm 0.79^{\mathrm{ab}}$ & $79.93 \pm 0.61$ & -52.972 & $<.001^{*}$ \\
\hline & $3^{\text {rd }}$ Month & $64.97 \pm 0.79^{\text {abc }}$ & $79.94 \pm 0.73$ & -75.694 & $<.001^{*}$ \\
\hline \multirow{4}{*}{$\begin{array}{l}\text { Progesterone(ng/ml) } \\
\text { (Day 21) }\end{array}$} & Baseline & $10.55 \pm 1.17$ & $10.59 \pm 0.81$ & -0.176 & 0.861 \\
\hline & $1^{\text {st }}$ Month & $11.38 \pm 0.93^{\mathrm{a}}$ & $10.49 \pm 1.17$ & 3.264 & $0.002^{*}$ \\
\hline & $2^{\text {nd }}$ Month & $12.31 \pm 1.31^{\mathrm{ab}}$ & $10.57 \pm 0.87$ & 6.044 & $<.001^{*}$ \\
\hline & $3^{\text {rd }}$ Month & $13.07 \pm 1.84^{\text {abc }}$ & $10.42 \pm 1.12$ & 6.732 & $<.001^{*}$ \\
\hline
\end{tabular}

$a=p<0.05$ compared with baseline, $b=p<0.05$ compared with $1^{\text {st }}$ month, $c=p<0.05$ compared with $2^{\text {nd }}$ month, $d=p<0.05$ compared with $3^{\text {rd }}$ month.

There was significant reduction in day 21 estrogen and significant increase in day 21 progesterone at 1 month, 2 months, and 3 months of exercise when compared their respective controls $(\mathrm{p}<0.05)$. At different stages of exercise; Day 21 estrogen showed significant reduction while significant increase was observed in day 21 progesterone at 1 month, 2 months and 3 months of exercise compare with baseline $(\mathrm{p}<0.05)$.

\section{DISCUSSION}

The analysis of ovarian reserve using serum Estrogen, FSH, LH and AMH in this study showed significant reduction in Estrogen, FSH and LH, while AMH showed significant increase at 3 months of exercise. The results of this study share comparisons with the study of McTiernan et al., (31) who reported statistically significant reduction of estrogen levels after 3 months of exercise. Also Christine et al., (32) reported that exercisers who abide by 150 to $225 \mathrm{~min} / \mathrm{wk}$, had an $18 \%$ reduction in estradiol 
concentrations compared with controls and a trend of percent change in estradiol levels with increasing exercise adherence was also observed their study. Another study showed that moderate levels of leisure-time physical activity enhance estrogen metabolism, especially among women with higher body weight (33). De Souza et al., (34) stated that exercise and participation in sports even if only of moderate intensity are associated with reduced levels of ovarian Estrogen. Some trials found no significant effects of exercise on estrogen levels (35-36). Loucks et al., (37) specified that physical activity limits pituitary secretion of luteinizing hormone (LH) and, to a lesser extent, follicle-stimulating hormone (FSH), which, in turn, limits ovarian stimulation and estradiol production. Atuegbu et al. (8) also reported reduction in estrogen, $\mathrm{LH}$ and FSH in premenopausal women after one month of exercise. A study done by Guner et al (38), observed that the examination of ovarian reserve hormones showed that the post-exercise E2 and FSH levels were reduced but not statistically significant compared to baseline within aerobic exercise group, also, in their study, the differences between the levels of $\mathrm{LH}$ and $\mathrm{AMH}$ within aerobic exercise group were not statistically significant, either. But, in their strength training group; the FSH levels were increased whereas, the AMH levels decreased and these were statistically significant. Two studies have shown that after 12 months of exercise, levels of hormones circulating in the blood decreased and further decrease was observed after reduction in body weight $(39,40)$ while another hypothesis stated that physical training does not significantly reduce levels of sex hormones but significantly reduces the expression of their receptors (41). However, some studies have observed that restricted energy availability following intense exercise caused the reduction in $\mathrm{LH}$ concentration via disruption of $\mathrm{GnRH}$ release in females $(42,43)$. In contrary, Loucks (44) observed in another study that exercise alone has no effect on $\mathrm{LH}$ pulsatility. Moreover, it was reported by Bullen et al. (45) that an 8-week moderate endurance exercise did not affect LH level and this finding was similar to another study which reported that LH concentration did not change after bicycle ergometer exercise in middle-distance runners (46). Kiranmayee et al. (22) conducted a study on 162 women at the ages of 19-42 and found that a moderate degree of physical activity was associated with higher levels of $\mathrm{AMH}$ in women under 30 years.

Physical activity may influence circulating estrogens by reducing adiposity, which decreases conversion of androgens to estrogens by aromatase or may have effects independent of a change in adiposity, including a reduction in insulin levels, which, in turn, increases SHBG levels and decreases estradiol bioavailability (21). Moreover, Bentz et al., (47) found that physical activity may have influence on the estrogen metabolism by favoring its transformation in the body to the low estrogenic products 2-hydroxyestrone (2OHE1). The product shows weak binding affinity to the estrogen receptor and, thereby, exerts antiproliferative effect on mammary cells. Basal estradiol $\left(E_{2}\right)$ levels may provide additional useful information for the evaluation of ovarian reserve. Early elevations in serum $\mathrm{E}_{2}$ are understood as a consequence of the advanced follicular development and early selection of a dominant follicle observed in older cycling women that are driven by rising FSH levels (48). Higher rates of cancelled assisted reproductive technology (ART) cycles have been demonstrated with $\mathrm{E}_{2}$ levels $<20 \mathrm{pg} / \mathrm{mL}$ or $\geq 80 \mathrm{pg} / \mathrm{mL}$ (49) but the value of day 3 estrogen in this study is $>20 \mathrm{pg} / \mathrm{mL}$ and $<80 \mathrm{pg} / \mathrm{mL}$ after 3 months of exercise. Measurement of both FSH and $\mathrm{E}_{2}$ on cycle day 3 may help to diminish the incidence of false-negative tests based on measurement of FSH alone, when both markers are precociously elevated, poor ovarian response is likely to occur (48) and this might result to infertility. 
The woman's age and assays of serum FSH in the early follicular phase were among the earliest and most useful parameters used for evaluation of ovarian reserve (50). One mechanism whereby ovarian secretion of hormones and growth factors may remain adequate despite agerelated decreases in oocyte quality and number (51-52) is through a compensatory effect of the early follicular phase FSH rise. Early follicular phase FSH elevations observed in older reproductive aged women may not only be due to a decrease in the number of recruitable follicles (and the resulting decrease in negative feedback), but may also be due to a relative resistance of the follicles to gonadotrophins. Regarding pregnancy occurrence, Klinkert et al., (53) suggested that it was less frequent among women with FSH levels $\geq 15 \mathrm{IU} / \mathrm{L}$ when compared to those with lower levels, but with no statistical significance.

The elevation of early follicular phase FSH represents a standard clinical marker of reduced ovarian reserve and diminished responsiveness of the ovary to ovulation induction (54).

Furthermore, there was significant increase in day 21 Progesterone in this study. Bhattacharya (17) stated that any level of progesterone more than $3 \mathrm{ng} / \mathrm{mL}$ confirms ovulation. Results from the Nurse's Health Study indicate reduced risk of ovulatory infertility in women doing vigorous exercise for at least 30 min daily (55). Also, a report of a cohort study indicated a 7\% relative risk reduction for ovulatory infertility for each additional hour of vigorous exercise per week in normalweight women (56). Exercise-induced weight loss has been shown to improve metabolic function and hormonal profiles, and often leads to significant rise in fertility $(7,16)$. Another study reported that an intense workout of at least 30 minutes per day reduced the risk of infertility associated with ovulation in women (17). While there are many studies describing the positive effects of physical activity on ovarian reserve markers and fertility outcomes in women of reproductive age (57-59), there is another study reporting that an intense level of physical activity is associated with adverse effects on fertility outcomes (60).

\section{CONCLUSION}

Three months moderate-to-vigorous exercise causes some changes in the reproductive hormone levels in females, with significant decrease in day 3 estrogen, $\mathrm{LH}, \mathrm{FSH}$, then, significant increase in $\mathrm{AMH}$ and day 21 progesterone hormone levels. From this result, physical exercise at moderate-to-vigorous level for three months may not adversely affect ovarian reserve but may increase the receptiveness of the follicles to FSH and LH which may lead to improved ovulation as signified by increased production of progesterone even at reduced levels of FSH and LH. Therefore, prolonged moderate-to-vigorous exercise may enhance fertility in premenopausal women.

\section{Acknowledgement: None}

\section{Conflict of Interest: None}

\section{Source of Funding: None}

\section{Ethical Approval: Approved}

\section{REFERENCES}

1. Howley ET. Type of activity: resistance, aerobic and leisure versus occupational physical activity. Med Sci Sports Exerc. 2001 Jun;33(6 Suppl):S364-9; discussion S419-20. doi: 10.1097/00005768200106001-00005. PMID: 11427761.

2. O'Connor D, Crowe M, Spinks W. Effects of static stretching on leg capacity during cycling. Turin 2005; 46 (1): 52-56.

3. Wilmore J, Knuttgen H. Aerobic Exercise and Endurance Improving Fitness for Health Benefits. The Phys Sports Med 2003; 31 (5): 45.

4. De Vos N, Singh N, Ross D, Stavrinos T. Optimal Load for Increasing Muscle Power During Explosive Resistance Training in Older Adults. Journal Gerontol 2005; 60A (5): 638-647. 
Njoku CM et.al. Effect of 3 months exercise on ovarian reserve and ovulatory status of premenopausal students of Nnamdi Azikiwe University, Nnewi Campus.

5. Amanat S, Ghahri S, Dianatinasab A, Fararouei M, Dianatinasab M. Exercise and Type 2 Diabetes. In: Xiao J, editor. Physical Exercise for Human Health. Singapore: Springer Singapore; 2020:91-105. doi:10.1007/978-981-15-1792-1_6

6. Wake AD. Antidiabetic Effects of Physical Activity: How It Helps to Control Type 2 Diabetes (2020). Diabetes, Metabolic Syndrome and Obesity: Targets and Therapy 2020; 13:2909-2923.

7. Norman RJ, Noakes M, Wu R, Davies MJ, Moran L, Wang JX. Improving reproductive performance in overweight/obese women with effective weight management. Human Reprod 2004; 10: 267-280.

8. Atuegbu CM, Meludu SC, Dioka CE, Onyenekwe CC, Onuegbu JA, Onah CE, Onyegbule OA, Analike RA, Udo JN. Effect of moderate - vigorous intensity physical exercise on female sex hormones in premenopausal university students in Nnewi, Nigeria. Int J Res Med Sci 2014; 2(4):1516-1520.

9. AL-Eisa E, Gabr SA, Alghadir AH. Effects of supervised aerobic training on the levels of anti-Mullerian hormone and adiposity measures in women with normo-ovulatory and polycystic ovary syndrome. J Pakistan Med Assoc 2017; 67:499.

10. Al-Nuaim AA, Al-Nakeeb Y, Lyons M, AlHazzaa HM, Nevill A, Collins P, Duncan MJ. The Prevalence of Physical Activity and Sedentary Behaviours Relative to Obesity among Adolescents from Al-Ahsa, Saudi Arabia: Rural versus Urban Variations. J Nutr Med 2012; 417589. https://doi.org/10.1155/2012/417589

11. Mariotti A. Sex steroid hormones and cell dynamics in the periodontium. Crit Rev Oral Biol Med 1994; 5:27-53.

12. Edlund M. Physiology of menstruation and menorrhagia. Inherited Bleeding Disorders in Women 2009; ISBN: 978-1- 4051- 69158, 12-33.

13. Goldenberg N, Glueck C. Medical therapy in women with polycystic ovary syndrome before and during pregnancy and lactation. Minerva Ginecol 2008; 60 (1): 63-75.

14. World Health Organization (WHO). International Classification of Diseases, 11th Revision (ICD-11) Geneva: WHO 2018.

15. Owolabi AT, Fasubaa OB, Ogunniyi SO. Semen quality of male partners of infertile couples in Ile-Ife,Nigeria. Nig J Clin Pract 2013; 16(1):37-40.

16. Clark AM, Ledger W, Galletly C, Tomlinson L, Blaney F, Wang X, Norman RJ. Weight loss results in significant improvement in pregnancy and ovulation rates in anovulatory obese women. Human Reprod 1995; 10:2705-2712.

17. Mohan BS. Mid-luteal phase plasma progesterone levels in spontaneous and clomiphene citrate induced conception cycles. J Obstetr Gynecol India 2005; 55:4.

18. Gupta S, Sharma D, Surti N, Kesavan S, Khanna P, Agarwal A. Ovarian reserve testing: systemic review of the literature. Arch Sci 2009; 5(1A): 143-150.

19. Broer SL, Mol BW, Hendriks D, Broekmans FJ. The role of antimullerian hormone in prediction of outcome after IVF: Comparison with the antral follicle count. Fert Ster 2009; 91:705-714.

20. Broekmans FJ, Kwee J, Hendriks DJ, Mol BW, Lambalk CB. A systematic review of tests predicting ovarian reserve and IVF outcome. Human Reprod Update 2006; 12: 685-718.

21. Nelson SM, Yates RW, Lyall H, Jamieson M, Traynor I, Gaudoin M, Fleming R. AntiMüllerian hormone-based approach to controlled ovarian stimulation for assisted conception. Human Reprod 2009; 24(4): 867-875.

22. Kiranmayee D, Praveena T, Himabindu Y, Sriharibabu M, Kavya K, Mahalakshmi M. The Effect of Moderate Physical Activity on Ovarian Reserve Markers in Reproductive Age Women Below and Above 30 Years. $J$ Human Reprod Sci 2017; 10(1):44-48.

23. Karl RH, Angela CT, Patrick MS, William JB, Michael RS, Nancy AK. Reproductive ageing and ovarian function: is the early follicular phase FSH rise necessary to maintain adequate secretory function in older ovulatory women? Human Reprod 2005; 20(1): 89-95.

24. Bedenk J, Vrtačnik-Bokal E, Virant-Klun I. The role of anti-Müllerian hormone (AMH) in ovarian disease and infertility. $J$ Assisted Reprod Genetics 2020; 37(1), 89-100.

25. Lv PP, Jin M, Rao JP, Chen J, Wang LQ, Huang CC. Role of anti-Müllerian hormone and testosterone in follicular growth: A cross-sectional study. BMC Endocr Disord 2020; 20:101. 
Njoku CM et.al. Effect of 3 months exercise on ovarian reserve and ovulatory status of premenopausal students of Nnamdi Azikiwe University, Nnewi Campus.

26. Kotlyar AM, Seifer DB. Ethnicity/Race and Age-Specific Variations of Serum AMH in Women-A Review. Front Endocrinol (Lausanne) 2021; 11:593216.

27. Victoria M, Labrosse J, Krief F, CedrinDurnerin I, Comtet M, Grynberg M. AntiMullerian Hormone: more than a biomarker of female reproductive function. J Gynecol Obstetr Human Reprod 2018; https://doi.org/10.1016/j.jogoh.2018.10.

28. Broer SL, Mol B, Dolleman M, Fauser BC, Broekmans FJ. The role of anti-Müllerian hormone assessment in assisted reproductive technology outcome. Curr Opinion Obstetr Gynecol 2010; 22(3), 193201.

29. Knauff EA, Eijkemans MJ, Lambalk CB, ten Kate-Booij MJ, Hoek A, Beerendonk CC, de Jong FH. Anti-Mullerian hormone, inhibin B, and antral follicle count in young women with ovarian failure. The J Clin Endocrinol Metab 2009; 94(3): 786-792.

30. van Disseldorp J, Lambalk CB, Kwee J, Looman CW, Eijkemans MJ, Fauser BC, Broekmans FJ. Comparison of inter- and intra-cycle variability of anti-Mullerian hormone and antral follicle counts. Human Reprod (Oxford, England) 2010; 25(1), 221-227.

31. McTiernan A, Tworoger SS, Rajan KB, Yasui Y, Sorenson B, Ulrich CM, Chubak J, Stanczyk FZ, Bowen D, Irwin ML, Rudolph RE, Potter JD, Schwartz RS. Effect of exercise on serum androgens in postmenopausal women: a 12-month randomized clinical trial. Cancer Epidemiol, Biomarkers Prev 2004; 13:1099-1105.

32. Friedenreich CM, Woolcott CG, McTiernan A, Ballard-Barbash R, Brant RF, Stanczyk FZ, Terry T, Boyd NF, Yaffe MJ, Irwin ML, Jones CA, Yasui Y, Campbell KL, McNeely ML, Karvinen KH, Wang Q, Courneya KS. Alberta physical activity and breast cancer prevention trial: sex hormone changes in a year-long exercise intervention among postmenopausal women. J Clin Oncol 2010; 28(9):1458-1466.

33. Matthews C, Shu XO, Jin F. Lifetime physical activity and breast cancer risk in the Shanghai Breast Cancer Study. $\mathrm{Br} J$ Cancer 2001; 84:994-1001.

34. De Souza MJ, Miller BE, Loucks AB. High frequency of luteal phase deficiency and anovulation in recreational women runners: blunted elevation in follicle-stimulating hormone observed during luteal-follicular transition. J Clin Endocrinol Metab 1998; 83:4220-4232.

35. Madigan MP, Troisi R, Potischman N. Serum hormone levels in relation to reproductive and lifestyle factors in postmenopausal women. Cancer Causes Control 1998; 9:199-207.

36. Monninkhof EM, Velthuis MJ, Peeters PH. Effect of exercise on postmenopausal sex hormone levels and role of body fat: A randomized controlled trial. J Clin Oncol 2009; 27:4492-4499.

37. Loucks AB, Mortola JF, Girton L, Yen SSC. Alterations in the hypothalamicpituitary-ovarian and the hypothalamicpituitary-adrenal axes in athletic women. $J$ Clin Endocrinol Metabol 1989; 68:402-411.

38. Guner C, Umit G, Faruk Y, Abdullah G, Esin G. Adverse Effect of Different Exercise Types on Ovarian Reserve. $J$ Edu Training Stud 2019; 7(1):115-120.

39. Brown JC, Winters-Stone $\mathrm{K}$, Lee $\mathrm{A}$ and Schmitz KH: Cancer, physical activity, and exercise. Comprehensive Physiology 2012; 2: 2775-2809.

40. Dierssen-Sotos T, Palazuelos-Calderon C, Jimenez-Moleon JJ, Aragones N, Jone M. Altzibar JM, Castano-Vinyals G, MartinSanchez V, Gomez-Acebo I, Guevara M, Tardon A, Perez- Gomez B, Amiano P, Moreno V, Molina AJ, Alonso-Molero J, Moreno-Iribas C, Kogevinas M, Pollan M and Llorca J: Reproductive risk factors in breast cancer and genetic hormonal pathways: A gene-environment interaction in the MCC-Spain Project Trynidad Dierssen-Sotos. BMC Cancer 2018; 18: 280.

41. Faustino-Rocha AI, Gama A, Oliviera PA, Alvarado A, Neuparth MJ, Ferreira R and Ginja M: Effects of lifelong exercise training on mammary tumorigenesis induced by MNU in female SpragueDawley rats. Clin Exp Med 2017; 17: 151160.

42. Birch K. Female athlete triad. $\mathrm{Br}$ Med $J$ 2005; 330:244- 246.

43. Loucks AB, Thuma JR. Luteinizing hormone pulsatility is disrupted at a threshold of energy availability in regularly menstruating women. $J$ Clin Endocrinol Metabol 2003; 88:297- 311.

44. Loucks AB. Exercise training in the normal female. Sports Endocrinol 2000; 165-180. 
Njoku CM et.al. Effect of 3 months exercise on ovarian reserve and ovulatory status of premenopausal students of Nnamdi Azikiwe University, Nnewi Campus.

45. Bullen BA, Skrinar GS, Beitins IZ, Carr DB, Reppert S, Dotson C, Fencl M, Gervino E, McArthur J. Endurance training effects on plasma hormonal responsiveness and sex hormone excretion. J Appl Physiol 1984; 56:1453-1463.

46. Rahnama N, Bambaeichi E, Reilly T. Effects of training on estradiol, progesterone, luteinizing hormone and follicle stimulating hormone in female. Cellular \& Molecular Biol Letters 2004; 9:117- 120.

47. Bentz AT, Schneider CM, Westerlind KC. The relationship between physical activity and 2-hydroxyestrone, 16-hydroxyestrone, and the 2/16 ratio in postmenopausal women. Cancer Causes Control 2005; 16: 455-461.

48. Speroff L, Fritz MA. Female infertility. In: Speroff L, Fritz MA, editors. Clin Gynecol Endocrinol Infertil. 7th edition. Philadelphia, Pa, USA: Lippincott Williams and Wilkins; 2005. pp. 1015-1022.

49. Frattarelli JL, Bergh PA,Drews MR, Sharara FI, Scott RT. Evaluation of basal estradiol levels in assisted reproductive technology cycles. Fertil Steril 2000; 74(3):518-524.

50. Tan SL, Rayston P, Caupbell S, Jacobs HS, Betts J, Mason B. Cumulative conception and live birth rates after in vitro fertilization. Lancet 1991; 339: 1390-1394.

51. Battaglia DE, Goodwin P, Klein NA, Soules MR. Influence of maternal age on meiotic spindle assembly in oocytes from naturally cycling women. Human Reprod 1996; 10:2217-2222.

52. Battaglia DE, Klein NA, Soules MR. Changes in centrosomal domains during meiotic maturation in the human oocyte. Molecular Human Reprod 1997; 2:845851.

53. Klinkert ER, Broekmans FJM, Looman CWN, Habbema JDF, TeVelde ER. The antral follicle count is a better marker than basal follicle-stimulating hormone for the selection of older patients with acceptable pregnancy prospects after in vitro fertilization. Fertil Steril 2005; 83(3):811814.

54. Toner J, Philput C, Jones. Basal folliclestimulating hormone level is a better predictor of in vitro fertilization performance than age. Fertil Steril 1991; 55:784-791.

55. Chavarro JE, Rich-Edwards JW, Rosner BA, Willett WC. Diet and lifestyle in the prevention of ovulatory disorder infertility. Obstetr Gynecol 2007; 110:1050-1058.

56. Rich-Edwards JW, Spiegelman D, Garland M, Hertzmark E, Hunter DJ, Colditz GA, Willett WC, Wand H, Manson JE. Physical activity, body mass index, and ovulatory disorder infertility. Epidemiol 2002; 13:184-190.

57. Kucuk M, Doymaz F, Urman B. Effect of energy expenditure and physical activity on the outcomes of assisted reproduction treatment. Reprod Biomed Online 2010; 20(2):274-279.

58. Saremi A, Shavandi N, Dezfolian M. The Effect of Physical Activity on Serum Levels of Anti-Mullerian Hormone and Fertility Parameters in Reproductive Age Women. $J$ Arak Univ Med Sci 2013; 16 (2):51-58.

59. Anderson K, Nisenblat V, Norman, R. Lifestyle factors in people seeking infertility treatment-a review. Austr New Zealand J Obstetr Gynaecol 2010; 50(1), 8-20.

60. Zanker CL. Regulation of reproductive function in athletic women: an investigation of the roles of energy availability and body composition. Br J Sports Med 2006; 40(6): 489-490.

How to cite this article: Njoku CM, Meludu SC, Dioka CE et.al. Effect of 3 months exercise on ovarian reserve and ovulatory status of premenopausal students of Nnamdi Azikiwe University, Nnewi Campus. Int J Health Sci Res. 2022; 12(1): 78-86. DOI: https://doi.org/ 10.52403/ijhsr.20220111 